\section{Bauinstandsetzen und Baudenkmalpflege}

Restoration

of Buildings and Monuments

Vol. 20, No. 2, 2014

\title{
Contents / Inhalt
}

Editorial

P. Zhang, F. H. Wittmann, T. J. Zhao and E. H. Lehmann

Investigations into the Water Repellent Surface Near Layer in Concrete

by Neutron Radiography

P. Zhang, F. H. Wittmann, M. Haist, H. S. Müller, P. Vontobel and T. J. Zhao

Water Penetration into Micro-cracks in Reinforced Concrete

P. G. Wang, F. H. Wittmann, P. Zhang, E. H. Lehmann and T. J. Zhao

Observation of Water Penetration into Cracked and Water Repellent SHCC

after Imposed Strain by Means of Neutron Radiography

R. X. Wu, P. G. Wang, F. H. Wittmann and T. J. Zhao

Composition and Properties of SHCC; Part I: Influence of Composition

of Cement-based Matrix on Strain Capacity and Crack Distribution

R. X. Wu, P. G. Wang, F. H. Wittmann and T. J. Zhao

Composition and Properties of SHCC; Part II: Influence of Elevated Temperatures

and Freeze-thaw Cycles on Strain Hardening Cement-based Composites

Y. Zhao, F. H. Wittmann, P. Zhang, P. G. Wang and T. J. Zhao

Penetration of Water and Chloride Dissolved in Water into Concrete under Hydraulic Pressure

\section{Short Contributions / Kurzbeiträge}

M. Zhang, P. G. Wang and F. H. Wittmann

Influence of Moisture Content on Chloride Diffusion in Concrete

W. P. Lu, F. H. Wittmann, P. G. Wang, Y. Zaytsev and T. J. Zhao

Influence of an Applied Compressive Load on Capillary Absorption of Concrete:

Observation of Anisotropy

Discussions or comments concerning papers published in this issue should be sent to the editorial office (office@aedificat.de) before July 31, 2014. 


\section{Short Notes / Mitteilungen}

Denkmal und Energie 2014 - Gebäudeertüchtigung im Klimawandel

Auch Bauten des 20. Jahrhunderts sind preiswürdig

Scholarships for the Advanced Masters in Structural Analysis of Monuments and Historical Constructions

\section{Companies Inform / Firmenmitteilungen}

Glashütte Lamberts Waldsassen stellt mundgeblasenes UV-Schutz-Glas vor: "restauro® UV"

New Books / Neuerscheinungen 


\section{Restoration of Buildings and Monuments \\ An International Journal}

\section{Editors}

Prof. Dr. F. H. Wittmann

Editor-in-chief

Aedificat Institute

Schlierbergstraße 80

D-79100 Freiburg

\section{Dr. A. Elena Charola}

Research Scientist

Smithsonian Museum Conservation Institute

Suitland, Maryland

USA

\section{Editorial Office}

Dipl.-Ing. Heidi Haberstroh

Tel.:+49 7618818650 ;

Aedificatio Verlag

Fax:+497618818651

Schlierbergstraße 80, 79100 Freiburg

Email: office@aedificat.de

\section{Editorial Board}

Dr. Kalliopi Aligizaki

Aedificat Institute

Freiburg, Germany

Dr. Carmen Andrade

Inst. E. Torroja

Madrid, Spain

Prof. Dr. Luigia Binda

DIS - Polytechnic of Milan

Milan, Italy

\section{Dr. Hilde De Clercq}

Royal Institute for Cultural Heritage Brussels, Belgium

Dr. José Delgado Rodrigues

National Laboratory of

Civil Engineering

Lisbon, Portugal
Prof. Dr. Andreas Gerdes

Fachhochschule Karlsruhe

und Forschungszentrum

Karlsruhe, Germany

Prof. Dr. Klaus Littmann

Leibniz Universität Hannover

Germany

Prof. Dr.-Ing. M. Raupach

IBAC, RWTH Aachen

Germany

Prof. Dr. Luc Schueremans

KULeuven

Heverlee, Belgium

Prof. Dr. Max J. Setzer

Universität Duisburg-Essen

Germany
Prof. Dr. Johan Silfwerbrand

Swedish Cement and

Concrete Research Institute

Stockholm, Sweden

Prof. Dr. K. Van Balen

K.U. Leuven

Heverlee, Belgium

Prof. Dr. D. Van Gemert

K. U. Leuven

Heverlee, Belgium

Véronique Vergès-Belmin Laboratoire de Recherche des

Monuments Historique

Champs-sur-Marne, France

Prof. Dr. Tie-jun Zhao

Qingdao Technological

University, Qingdao, China 


\title{
Restoration of Buildings and Monuments
}

\author{
An International Journal
}

\author{
Bauinstandsetzen und Baudenkmalpflege \\ eine internationale Zeitschrift
}

\begin{abstract}
Aims and Scope
- Studies of deteriorating mechanisms

- Preventive measures and durability design

- Assessment of the actual state

- Maintenance strategies

- Strengthening and rehabilitation

- Repair engineering and ecological impact
\end{abstract}

Restoration of Buildings and Monuments (RBM), an international journal, publishes invited review articles, original papers, and short communications in the wide field of durability, maintenance and restoration of buildings, structures, and monuments. Contributions present recent results from original research and new experiences from practice. The wide field covered by this journal can be subdivided into six main areas:

Papers are published in English or in German with summaries and keywords in both languages.

\section{Subscription}

Restoration of Buildings and Monuments (RBM) is published bimonthly by Aedificatio Publishers, Freiburg, Germany. The subscription rate for volume 20, 2014, containing six issues, is EUR 170,-- plus postage. You can subscribe via your bookstore or directly by e-mail: office@aedificat.de. The subscription can be cancelled with three-month term to the end of the year; otherwise it is extended by a further year. Individual issues published recently can be purchased for EUR 30,00 each. Volumes 1 to 19 will be available on CD soon. Restoration of Buildings and Monuments is available as hard copy (ISSN 1864-7251) or as electronic version (ISSN 1864 - 7022).

If you are interested, you may obtain a free sample copy by contacting the publishers:

Aedificatio Publishers Freiburg

Schlierbergstraße 80, D-79100 Freiburg

Tel.: +49-761-881 86 50; Fax: +49-761-881 86 51; e-mail: office@aedificat.de, Internet: www.aedificat.de

\section{Copyright}

Copyright (C) 2014, Aedificatio Publishers, Freiburg. All rights reserved. No part of this publication can be reproduced, stored in a retrieval system, or transmitted, in any form or by any means, electronic, mechanical, photocopying, recording, scanning or otherwise, except as described below, without the permission in writing of the Publisher.

Copying of articles is not permitted except for personal and internal use, to the extent permitted by national copyright law, or under the terms of a license issued by the national Reproduction Rights Organization. Requests for permission for other kinds of copying, such as for general distribution, should be addressed to the Publisher.

Statements and opinions expressed in the articles and communications are those of the individual authors and not the statements and opinions of the Publisher. Aedificatio Publishers assumes no responsibility or liability for any damage or injury to persons or property arising out of the use of any materials, instructions, methods, or ideas contained in this journal. 


\section{Reprints and Advertisements}

Reprints of published articles can be ordered by respective authors directly from the Publishers.

Advertising orders and inquiries should be addressed to:

Aedificatio Publishers, Advertising Department

Schlierbergstraße 80

D-79100 Freiburg

Tel.: +49-761-881 86 50; Fax: +49-761-881 8651

e-mail: office@aedificat.de; Internet: www.aedificat.de

\section{Abstracts of Papers published in RBM are included in Databases}

AATA Online:

Abstracts of International Conservation Literature, http://www.aata.getty.edu/NPS/

Getty Institute,

Conservation Abstracts, Los Angeles, USA, www.getty.edu/conservation/

Cambridge Scientific Abstracts,

Ann Arbor, MI 48108-3218, USA, www.csa.com

Institut national du patrimoine (inp),

F-93210 Saint-Denis La Plaine, www.inp.fr

ICONDA, The International Construction Database,

Fraunhofer-Informationszentrum Raum und Bau IRB, Stuttgart, www.irbdirect.de/iconda/

\section{RBM on the web}

Table of contents of volume 1 to volume 19 can be found on the internet together with an author's and subject index. The table of contents of forthcoming issues can be found on the web two to four weeks prior to each issue's publication.

www.aedificat.de/rbm 


\title{
Restoration of Buildings and Monuments An International Journal
}

\author{
Aedificatio Publishers, Freiburg, Germany \\ Tel.: +49-761-881 8650 \\ E-mail: office@aedificat.de
}

\section{Guidelines for authors on how to prepare and submit contributions}

\section{General Information}

In the international journal Restoration of Buildings and Monuments invited review papers, original papers, and short communications are published.

Contributions, either original papers or short communications, can be submitted in English or in German. All contributions should contain new and unpublished results which are to be described as concisely as possible. Papers should not be over 16 pages long, while short communications should have a maximum of 6 pages.

Authors should submit their contribution as pdf document and in one of the following formats, namely, Frame Maker, Word or RTF to the publishers: office@aedificat.de.

If there is more than one author please indicate the author to whom correspondence shall be addressed (corresponding author). It will be helpful if you can provide us with the email address of the corresponding author.

Figures should not be incorporated within the text but should rather be submitted as separate files, if possible in TIF or EPS format. Reference to the figures must be made in the text and figure captions should be included so as to ensure their appropriate placement. Color prints should be included if absolutely necessary only and their reproduction requires the approval of the editor. Experimental results should be presented either as tables or in a graphical format, but not under both options.

Submitted papers will pass a critical and anonymous peer review process following which authors may be asked to revise their contributions accordingly.

Authors will receive 2 copies of the issue in which their contribution is published free of charge. These complimentary copies will be sent to the corresponding author. Reprints of individual contributions can be produced if ordered in advance.

\section{Layout}

In principle, no special fonts are required and formatting should be reduced to an absolute minimum. In particular, avoid the use of the space-bar and the tab key.

The first page should only present the title of the paper, names (with only the initials of the given names) and affiliation of the authors and an abstract (English and German in case the paper is written in German) covering the most important results. Not more than five keywords should be added.

\section{Equations, Figures and Tables}

Equations should be numbered consecutively with the numbers placed at the right edge of the page in brakkets (e.g. (1)). Equations should be referred to in the text as eq. (1). Both tables and figures should also be numbered consecutively. In the text reference to tables and figures should be made as Table 1 and Fig. 1 respectively. Captions for tables should be placed above them while those for figures should be placed below.

Please avoid whenever possible colors to distinguish different lines in one figure. Use different symbols or solid lines, dashed lines, and dotted lines instead. Text in figures must be big enough to be readable after reproduction. 


\section{References}

References are numbered consecutively following their appearance in the text. Numbers are given in square brackets (e.g. [1,2] or [4-6]). The list of references is placed at the end of the manuscript under the heading References. Format for the references is as follows:

(1) for a paper published in a professional journal: author's name(s) with initials, the title of the paper (in italics), the title of the journal (the official abbreviation may be used), volume (bold), year of publication in brakkets, followed by first and last page number (see [1] below);

(2) for papers published in Proceedings and other edited volumes: author's name(s) with initials, title of the contribution (in italics), first and last page number, title of the volume, editor(s) with initials, the publishing company, place and year of publication (see [2] below);

(3) for books: names of the authors or editor(s) with initials, the title (in italics), the publishing company, place and year of publication (see [3] below).

\section{Examples:}

1. G. Croci, The Basilica of St. Francis of Assisi after the Earthquake of 26 September 1997, International Journal for Restoration of Buildings and Monuments 4 (1998) 321 - 335

2. V. Slowik, E. Schlattner and T. Klink, Strain Monitoring at Concrete Structures by Using Fibre Bragg Rating Sensors, in Durable Reinforced Concrete Structures, P. Schwesinger and F.H. Wittmann, Editors, Aedificatio Publishers, Freiburg (1998) 477-493

3. Z. P. Bazant and M. Kaplan, Concrete at High Temperatures, Longman Group Ltd., London (1996) 
